systems if they form mesophases ${ }^{10}$. Polymers below their glass transition can retain an induced non-centrosymmetrical arrangement, which is essential for frequency doubling. This gives liquid-crystal polymers a major advantage over their monomer counterparts. Furthermore, polymeric systems exhibit high laserdamage thresholds that allow them to be used with powerful lasers, which would rapidly damage inorganic or organometallic materials.

An understanding of the structure, molecular dynamics and physical properties of mesogenic side-chain polymers, and of their behaviour in electric and magnetic fields, is slowly emerging as a result of X-ray, optical nuclear magnetic resonance and dielectric studies ${ }^{3,4,11}$. But many questions remain unanswered and several aspects need clarification for the full technological potential of these new materials to be realized. Much needs to be done on controlling molar mass (highmolar-mass materials are only now being synthesized); the effect of the geometry of the main chain (stereoregularity) on the

NEWSANDVIEWS

material properties and the wide variety of chemical structures that could be incorporated into the polymers have yet to be explored. In addition, polymeric systems that form mesophases under the influence of solvents have received little attention ${ }^{11}$ but are expected to give rise to some important developments in the formation of functional LangmuirBlodgett films.

1. Gray, G.W. The Molecular Structure and Properties of Liquid Crystals (Academic, New York, 1962)

2. Cabrera, I. \& Krongauz, V. Nature 326, 582-585 (1987)

3. Shibaev, V. P. \& Plate, N.A. Adv. Polym. Sci. 60/61, 173252 (1984).

Finkelmann, N. \& Rehage, G. Adv. Polym. Sci. 60/61, 99 $172(1984)$.

5. Kalisky, Y. \& Williams, D. J. Macromolecules 17, 292-296 (1984)

6. Dobb, M. G. \& McIntyre, J. E. Adv. Polym. Sci. 60/61, 61-98 (1984)

. Engel, M. et al. Pure appl. Chem. 57, 1009-1014 (1985)

8. Araki, K., Attard, G. S. \& Williams, G. J. molec Electron. (in the press)

9. Coles, H.J. \& Simon, R. Polymer 26, $1801-1806$ (1985) 10. Williams, D.J. (ed.) ACS Symp. Ser. No. 233 (1983).

11. Attard, G. S. \& Williams, G. Chem. Br. 22, 919-924 (1986)

George Attard and Graham Williams are at the Edward Davies Chemical Laboratories, University College of Wales, Aberystwyth SY23 INE, UK.

\title{
Forest ecology
}

\section{Tree boundaries on the move}

\section{Peter D. Moore}

JusT as Macbeth made an unfortunate error of judgment in assuming that Great Birnam Wood could never move to Dunsinane, so can the inherent mobility of forests easily be underestimated. The climatic fluctuations of the past two million years have resulted in dramatic migrations of forests, and recent research suggests ${ }^{1}$ that some trees have achieved surprisingly rapid rates of movement using particularly mobile vectors, such as the now-extinct passenger pigeon. Not only are the means of travel somewhat obscure, so are the migration routes: new biochemical and cytological surveys show ${ }^{2}$ that the origins of many tree populations, even the Caledonian forests of Scots pine in Scotland, are not as clear-cut as might be thought.

Migration rates of forests can be studied by the measurement of age distribution along transects at right angles to the forest edge $^{3}$, but the forest front is not always easily discernible. A more common method that provides a broader view of movement is the collation of data from pollen diagrams. Movements of lines of equal pollen input (isopolis) through time can be assumed to reflect the movements of tree species ${ }^{4}$. Studies of the polewards movements of trees since the end of the last glaciation about 10,000 years ago demonstrate that migration rates were surprisingly rapid, often in excess of 300 m per year ${ }^{5}$. In North America, Webb' $\mathrm{cal}^{-}$ culates that the forest was advancing by between 1 and $8 \mathrm{~km}$ per generation, depending on the tree species involved. Even more remarkable, as Webb points out, is the similarity between the rates of movement of tree species despite very different modes of dispersal. The migration rate of the white pine (Pinus strobus), for example, with its seeds dispersed by winds, is equalled by that of the heavyfruited oaks (about $350 \mathrm{~m}$ per year) ${ }^{5}$.

This rapid rate of movement can only be achieved by heavy seeds if they are transported by a mobile vector. Although some mammals move and store seeds, their ability to transport viable propagules over long distances is limited. Many birds, such as jays, nutcrackers and titmice, hoard food but their capacity to relocate caches of nuts is prodigious ${ }^{6}$ and they are unlikely to carry them far beyond the forest margin. Migratory species are more likely to provide a suitable vector. Studies ${ }^{7}$ on the island of Surtsey, off Iceland, reveal that small passerines such as the snow bunting can carry viable seeds in their gizzards from mainland Britain about $1,000 \mathrm{~km}$ away. In North America, Webb suggests the passenger pigeon (Ectopistes migratorius) was a vector, but this bird did not carry and store seeds, so its effectiveness depended on the survival of seeds passing through the gut. She argues that because the crop of a passenger pigeon could hold up to 30 acorns the possibility of bird death, regurgitation or viable passage was considerable, especially taking into account the vast flocks of these birds which once foraged and migrated over wide areas of North America. There is archaeological evidence for the presence of the passenger pigeon since early in the present interglacial period.

There were no passenger pigeons in the British Isles, yet the rates of advance of oaks and hazel were similar to those of North America at that time. Perhaps the wood pigeon (Columba palumbus) was the major vector on the British side of the Atlantic. Eastern European populations of this bird are at present clearly migratory ${ }^{8}$, although oceanic birds tend to be more sedentary. It is impossible to say, of course, how the species behaved 10,000 years ago.

When dealing with islands, there are further problems to be considered resulting from the lowered sea level during glacial times and the opportunities for warmth-demanding trees to find refugia in low coastal sites. If such currently submerged refugia existed, then the isopoll lines should provide evidence for them. There is indeed a suggestion of spread from isolated western locations in the present-day interglacial period for hazel and for alder.

An alternative approach in the search for roots has been supplied by the monoterpene and isoenzyme studies on the Scots pine (Pinus sylvestris) of Kinloch, Westfall and Forrest ${ }^{2}$. The Caledonian race of this species is isolated from other populations, as the pine became extinct over much of England and Wales by about 3,000 years ago, although it survived longer in Ireland. Scots pine was an early postglacial invader of southern England, almost certainly as a result of migration across the land link with continental Europe, but it expanded in eastern Scotland only about 7,000 years ago. Was this invasion an extension of the English pine northwards, or did the Scots pine have a separate origin? The biochemical evidence suggests the latter, for the Scottish trees display little genetic affinity with those of mainland Europe. The distinctiveness of the Caledonian race suggests that it has been isolated for a long time and that its origin was in western refugia, perhaps in the region of the Hebrides.

1. Webb, S.L. Quat. Res. 26, 367-375 (1986).

2. Kinloch, B.B., Westfall R.D. \& Forrest G.I. New Phytol. $104,703-729$ (1986)

3. Leak, W.B. \& Graber, R.E. Ecology 55, 1425-1427(1974)

4. Huntley, B. \& Birks, H.J.B. An Atlas of Past and Presen Pollen Maps of Europe: 0-13,000 Years Ago (Cambridge University Press, 1983)

5. Davis, M.B. in Forest Succession: Concepts and Applica tions (eds West, D.C., Shugart, H.H. \& Botkin, D. B.) 132 153 (Springer, New York, 1981)

6. Shettleworth, S.J. Scient. Am. 248 (2). 86-94 (1983)

7. Fridriksson, S. Surtsey: Evolution of Life on a Volcanic lsland (Butterworths, London, 1975).

8. Cramp. S. et. al. The Birds of the Western Palearctic Vol, 4 (Oxford University Press. 1985)

Peter D. Moore is in the Department of Biology, King's College London (KOC), Campden Hill Road, London W8 7AH, UK. 